\title{
Effects of Interest Rate and Exchange Rate on Volatility of Market Index at Dhaka Stock Exchange
}

\author{
DEWAN MUKTADIR-AL-MUKIT ${ }^{*}$
}

\begin{abstract}
The paper investigates the effects of the exchange rates and interest rates on stock market performance by using monthly time series data for the economy of Bangladesh, over the period of 1997 to 2010. This study uses econometric techniques of measuring the long and short term relationship between variables using the concept of Cointegration and Error Correction Model and analysis of Variance Decomposition. Causal relationships have been investigated using Granger causality test. By employing Cointegration technique it is observed that in the long run, a one percent increase in exchange rate and in interest rate contributes $1.04 \%$ increase and $1.71 \%$ decrease in market index respectively. The estimated error correction coefficient indicates that 7.8 percent deviation of stock returns are corrected in the short run. Finally, Granger causality analysis suggests the existence of a unidirectional causality from market index to exchange rate and from interest rate to market index.
\end{abstract}

Keywords: Cointegration, Granger Causality. Exchange rate, Interest rate, DGEN index

\section{INTRODUCTION}

A well functioning financial system boosts economic growth through proper and efficient allocation of resources. As a part of financial system, the importance and role of stock market towards achieving economic growth is crucial. The functioning of stock market depends on investors' buying and selling decisions which is influenced by a number of economic factors. Frequent changeability rhythm of stock prices makes themarket considered to be risky one and for which investors are always interested to be informed about impacting factors of stock prices and also the extent of such impact. There are many pieces of research which have investigated the influences of economic factors on the performance of stock market. Among a number of economic variables interest rate and exchanger rate are considered to be key one which exert a significant influence on stock prices.

*Lecturer, Faculty of Business Administration, Eastern University, Dhaka. 
The country's first stock exchange, Dhaka Stock Exchange (DSE) was established in 1954 which commenced its operation in 1956. It started its journey with 196 listed securities and total paid up capital of Taka 4 billion. Economic reforms during 1990s bring an immense change in financial sector of Bangladesh. The reforms were aimed at moving towards an open economy system where different initiatives were targeted like making the currency convertible on the current account, abolishing control on movements of foreign private capital, export promotion, reduction of import duty at a greater extent. High development of the market is noticeable after initiating the financial sector reforms. The number of listed securities of DSE stood at 153 at the end of period 1993. On November, 2012 there are total 284 companies listed in DSE. The total market capitalization is Taka 3680billion. On the other hand, after independence Bangladesh had been maintaining various pegged exchange rate regimes where it followed fixed exchange rate regime from January 1972 to May 2003 and a floating exchange rate regime since June 2003. "The experiences of other countries in the region show that floating regime generates greater volatility in exchange rates and this sort of uncertainty is likely to affect adversely the overall trade and investment climate which is already afflicted by many unfavorable elements in Bangladesh" (Islam, 2003). The activities in the financial markets and their relationships with the macroeconomic factors have been assumed significant important as the economic reform brings more exposure to economic and financial risks along with efficient functioning of the financial sector of the economy. As a part of financial system capital market plays a vital role for economic development acting as an intermediary between investors and firms. Besides a number of factors stock market is affected largely by the interest rate volatility as well as fluctuations in the foreign exchange rates. Foreign exchange rate and interest rate risks are important financial and economic factors affecting the value of common stocks (Joseph et al., 2006). So, it is needed to estimate the effects of these variables on stock market return in Bangladesh.

It is believed that the stock prices and interest rates are negatively correlated. An expansionary monetary policy causes the interest rate to decline. A reduction in interest rates leads to lower cost of borrowing. It has two impacts on stock market. People tend to take more loans at a lower cost to invest in stock market. Moreover, lower interest rate makes investors reluctant to invest or keep money in the bond market. So they tend to move money from the bond market to the equity market. This higher demand causes price of stock to raise sharp.

In an open market economy, movement of capital between countries affects the price of stock through the change of the exchange rate. The capital inflow results appreciation of domestic currency through supply of foreign currency 
which reduces the competitiveness of exporter of domestic country. This lower competitiveness of domestic production weakens the price of stock. On the other hand, devaluation of local currency exerts positive impact on exporters by making export cheaper and import costly. Hence, the price of stock of exporting firms reacts positively to such devaluation. Besides, capital inflow increases the supply of money with which the interest rategoes down. This lower interest rate tends to increase the demand for stock and in turn such higher demand causes price of stock to boost up.

This paper analyzes the relationship of stock market index with exchange rate and interest in Bangladesh between 1997 and 2010 using monthly time series data. For this purpose the paper employs different econometric techniques in analyzing statistical phenomenon of these variables.

\section{LITERATURE REVIEW}

Considerable amount of research studies can be found demonstrating the relation between stock market and macroeconomic variables. In recent periods a number of studies focus on the dynamic relationship of stock market with exchange rate and interest rate.

Modigliani (1971) and Mishkin (1977) point that lower interest rates increase stock prices which in turn leads to increased business investment. Normally, a low interest rate leads higher capital flows to the stock market in expectation for a higher rate of return where a high interest rate encourages more savings in banks and consequently reduces the flow of capital to the stock markets. The study of Fama and Schwert (1977) reveals inverse relationship between common stock returns and treasury bill rates. Mukherjee and Naka (1995) studied the association of stock prices in Tokyo Stock market with a set of macroeconomic variables. Their Vector Error Correction Model of the study suggests a positive relationship between stock price and money supply, stock price and industrial production, stock price and exchange rate. Using Cointegration test, Granger causality and Impulse response analysis, Hasan and Tarij (2009) explored the relationship between equity prices of Pakistan stock market with the money supply, foreign exchange rate, Treasury bill rate, and the CPI. They found that the relationship of the interest rate and the exchange rate with equity market returns is negative. Leon (2008) uses GARCH model to determine the relationship between Korean Stock Price Index 200 (KOSPI) and Negotiable Certificates of Deposits (Korea NCD 91-Day yield) using weekly data from 1992 to 1998 and the study reveals that the conditional market returns have a negative and significant relation with the interest rates. Applying Cointegration test, 
Vector Error Correction Model and Granger Causality test, Imam and Amin (2004) examined the association between DSE stock index and a set of macroeconomic variables comprising money supply, GDP, interest rate, 91 day T-bill rate and Industrial production index. In the VECM test, they found that the lagged stock index was adjusted to long run equilibrium by 43.82 percent by the combined lagged influence of all the selected macroeconomic variables. The study also discovers a unidirectional causality from interest rate change to stock market return. Alam and Uddin (2009) examined the impacts of interest rates on stock exchange for fifteen developed and developing countries including Bangladesh. They used the monthly Stock Exchange Index and interest rate data from January 1998 to March 2003 of fifteen countries and run the panel regression. For all of the countries, it is found that interest rates have significant negative relationship with share prices.

The relationship between stock returns and exchange rates has got much more attention especially after the 1997 financial crisis in Asian countries. The crisis results stock prices and exchange rate to fall across Asian markets significantly. Numerous studies suggest that the changes in expected stock returns should be linked to the changes in exchange rates.To examine the origin and the subsequent impact of the 1997 Asian Financial Crisis, Khalid and Kawai (2003) attempts to assess the relationship of three financial market variables foreign exchange rates, stock market prices and interest rates of nine East Asian countries using VAR model. Hashimoto and Ito (2004) also attempt such study on the eight countries in the region during the period of Asian currency crisis, 1997-1999 and considered two variables-exchange rate and stock price. The researchers of both studiesbelieve that the sharp depreciation of the Thai baht causes depreciation of other currencies in the region which in turn contributes to the collapse of the stock markets of that region. But the findings of Granger causality and impulse response function of Khalid and Kawai's (2003) study does not show strong evidence for such contagion among different markets and different countries within the Asian region. Whereas the later study shows that Indonesian, Korean and Thai currency depreciation and Hong Kong stock price declines had impacts on other currencies and stock prices in the region during the crisis period.

Aggarwal (1981) examined the influence of exchange rate on U.S. Stock market prices for the period of 1974 to 1978 and the study shows a positive correlation between the variables. He argues that a change in exchange rates could change stock prices because variations in exchange rates alter firms' profits which in turn affect stock prices. Jorion (1990) shows that a currency appreciation might decrease stock prices by reducing firms' profits. Abdalla and 
Murinde (1997) used monthly data from 1985 to 1994 to assess the relationship between stock prices and exchange rate for four Asian countries. Their Granger causality analysis suggests the existence of unidirectional causality from exchange rate to stock prices in India, Pakistan and Korea; and from stock price to exchange rate in Philippines. Kumar (2008) examined the affiliation between Stock prices and Exchange Rate on the context of Indian economy by using Cointegration and Granger causality test. His study shows bidirectional linear and nonlinear granger causality between stock returns and exchange rates. In another study, Muhammad and Rasheed (2002) studied the relationship between stock prices and exchange rates for four South Asian countries. No significant relationship between the variables is found for the country of India and Pakistan but a bidirectional relationship is found for the country of Bangladesh and Srilanka. Similar study has been conducted by Rahman and Uddin (2009) for three Asian countries named as Bangladesh, India and Pakistan. Their study shows no causal relationship between stock prices and exchange rates in the countries. The study of Ahmad et al (2010) examines the relationship between stock return, interest rate and exchange rates in Pakistani economy. They conclude that the change in interest rate has a negative while change in exchange rate has a positive impact on stock return. The study of Banerjee and Adhikarys (2009) shows the dynamic effects of changes in interest rates and exchange rates on the stock market return in Bangladesh. But the results from VAR models suggest independence between the variables.

\section{METHODOLOGY AND DATA}

The study investigates the relationship between market index with exchange rate and interest rate. The data set comprises of monthly time series data for Bangladesh over the total 168 sample periods of January, 1997 to December, 2010. The sources include International Financial Statisticspublished by International Monetary Fund (IMF), monthly economic trends published by Bangladesh Bank and Dhaka Stock Exchange website (dsebd.org).

Market Index: The DSE General (DGEN)Index has been chosen as the measure of stock market performance which captures the daily price movements of equities at the stock exchange.

Exchange Rate: Exchange rate is the value of the domestic currency in terms of foreign currency. The exchange rate is stated in terms of Bangladeshi Taka against US (United States) currency of Dollar.

Interest Rate: Interest rate is proxied by the Schedule banks' weighted average interest rates on saving deposit. 
The summary descriptive statistics of the study variables are shown in Appendix-1.The structural model to estimate the relationship between log transformed variables is stated below:

$L Y_{t}=\beta_{0}+\beta_{1} L E X R_{t}+\beta_{2} L I N T_{t}+\varepsilon_{t}$

Where,

$\mathrm{Y}$ is the Log DSE General (DGEN) Index

LEXR is the Log Exchange Rate

LINT is the Log Interest Rate

$\beta_{0}$ and $\beta_{i}$ are the parameters known as the intercept and slope coefficient and $\varepsilon$ is the classical random disturbance term.

In order to check multicollinearity among independent variables, a correlation analysis has been performed. Multicollinearity is a situation in which two or more explanatory variables in a multiple regression model are highly linearly related. We made the decision based on the rule of thumb that if the pair wise correlation between two regressors is in excess of 0.8 the regression is said to have significant multicollinearity problem.

In order to avoid a spurious regression situation the variables in a regression model must be stationary or cointegrated. When working with non- stationary time series, there is need to test the presence of unit roots in order to avoid problem of spurious regressions. To check for non-stationarity property, the data are subjected to Augmented Dickey and Fuller test (ADF test). ADF is performed by adding the lagged values of the dependent variable $\Delta \mathrm{Y}_{\mathrm{t}}$. The following regression is for ADF test purpose:

$\Delta Y_{t}=\beta_{1}+\beta_{2} t+\delta Y_{t-1}+\alpha_{i} \Sigma \Delta Y_{t-i}+\varepsilon_{t}$

Where $\varepsilon_{t}$ is a white noise error term and $\Delta Y_{t-1}=\left(Y_{t-1}-Y_{t-2}\right)$ and so on are the number of lagged difference term which is empirically determined. Using Schwarz Information Criterion (SIC) the lag length is selected automatically by E-views software. The null hypothesis of ADF test states that a variable is nonstationary and the null hypothesis of non-stationary is rejected if the calculated $\mathrm{ADF}$ statistics is less than the critical value.

Our next step is to determine whether the variables have a stable and nonspurious cointegrating relationship among themselves. Theconcept of Cointegration is thatnon-stationary time series are cointegrated if a linear combination of these variables is stationary. For the purpose of testing Cointegration we have chosen the Johansen (1979) procedure. 
If there is at least one cointegrating relationship among the variables, then the causal relationship among these variables can be determined by estimating the Vector Error Correction Model (VECM). It provides information about the speed of adjustment to long run equilibrium and avoids the spurious regression problem (Engle and Granger, 1987). Error Correction Mechanism is used to tie the short run behavior of an economic variable to long run value. After VECM is estimated, then we employ Variance Decompositions and Impulse Response Function to investigate the behavior of an error shock to each variable on its own future dynamics as well as on the future dynamics of the other variables in the VECM system. Variance decomposition measures the percentage of forecast error of variation that is explained by another variable within the short-run dynamics and interactions.

The final step of our analysis is to test for causality between market index and it's determinants in the long run. The results are based on Granger causality test. Granger causality is a technique for determining whether one time series is useful in forecasting another. A variable $\left(\mathrm{y}_{1}\right)$ is said to Granger-cause another $\left(\mathrm{y}_{2}\right)$ if the present value of $y_{2}$ can be predicted with greater accuracy by using past values of $y_{1}$, all other information being identical (Thomas 1997:461).

\section{ANALYSIS AND FINDINGS}

\subsection{Test for Multicollinearity}

To check existence of multicollinearity among independent variables, a correlation analysis has been conducted. The result of the correlation analysis is reported in Table-1. As none of the correlation coefficient between independent variables is greater than 0.80 ; so, no multicollinearity problem amongst independent variables exists.

TABLE 1 PEARSON COEFFICIENT OF CORRELATION MATRIX

\begin{tabular}{|c|c|c|}
\hline & LEXR & LINT \\
\hline LEXR & 1.000000 & -0.176561 \\
\hline LINT & -0.176561 & 1.000000 \\
\hline
\end{tabular}




\subsection{Stationarity Test}

The Table-2 shows ADF statistic used to check the presence of unit root in data DSE General Index, Exchange Rate and Interest rate.

TABLE 2

RESULTS OF ADF TEST

\begin{tabular}{|l|c|c|}
\hline \multirow{2}{*}{ Variables } & \multicolumn{2}{|c|}{ ADF Test Statistic } \\
\cline { 2 - 3 } & Level & First difference \\
\hline LDGEN & -1.848705 & $-10.25870^{* * *}$ \\
\hline LEXR & -1.739905 & $-13.29859^{* * *}$ \\
\hline LINT & -1.890694 & $-10.59303 * * *$ \\
\hline \multicolumn{3}{|c|}{ Test Critical value } \\
\hline 1\% level & -4.014288 & -3.469933 \\
\hline 5\% level & -3.437122 & -2.878829 \\
\hline 10\% level & -3.142739 & -2.576067 \\
\hline
\end{tabular}

Note: $* * *$ indicates statistically significant at the $1 \%$ level.

The results in Table 2 shows that ADF tests fail to reject the null of nonstationary for all of the variables at level. After first differencing the result shows that LDGEN, LEXR and LINT became stationary at the $1 \%$ significant level, implying that all the variables are first order integrated I(1).

The following graph shows the combined relationship of stationarity and nonstationarity among the variables.

FIGURE 1:Trend with stationary and non-stationary

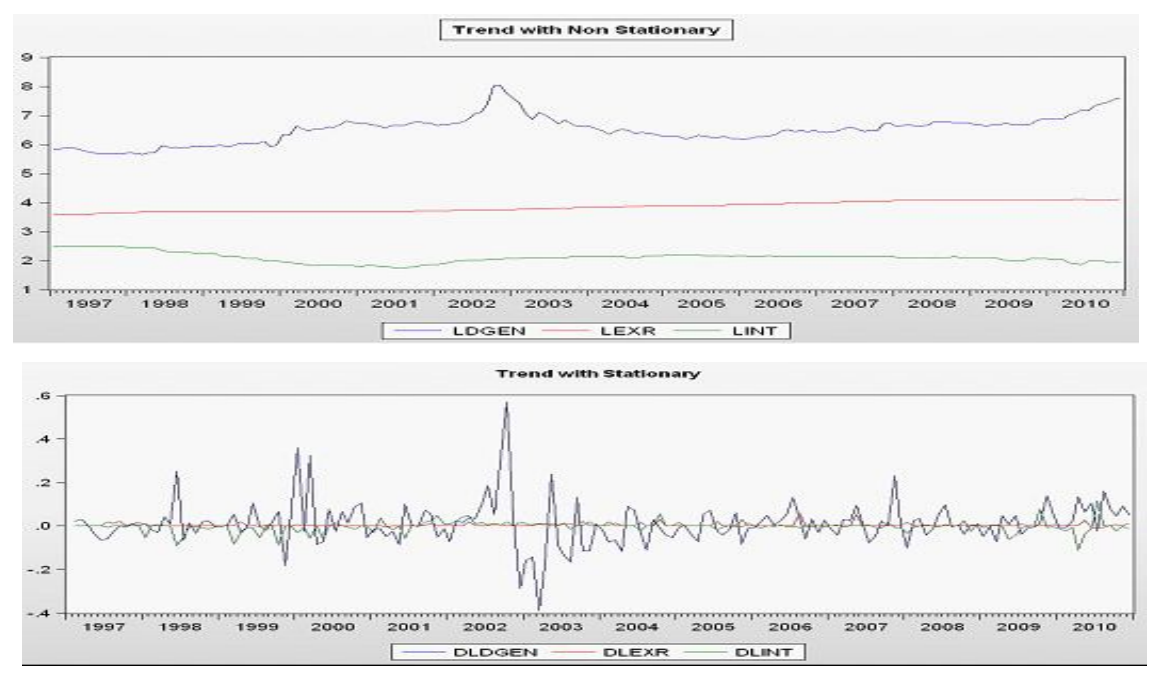




\subsection{The Ordinary Least Square (OLS) Regression Model}

The log-transformed DGEN index and others causative factors have been used in developing the OLS models. The OLS results have been presented in the following Table-3.

TABLE 3

OLS REGRESSION RESULTS

\begin{tabular}{|l|r|r|r|r|}
\hline & Coefficient & Std. Error & t-Statistic & p-values \\
\hline \multicolumn{1}{|c|}{ C } & 5.957821 & 0.716049 & 8.320409 & 0.0000 \\
\hline LEXR & 0.980640 & 0.154889 & 6.331238 & 0.0000 \\
\hline LINT & -1.535711 & 0.145883 & -10.52698 & 0.0000 \\
\hline R-squared & 0.521808 & \multicolumn{2}{|c|}{ Mean dependent var } & 6.504552 \\
\hline Adjusted R-squared & 0.516012 & S.D. dependent var & 0.470912 \\
\hline S.E. of regression & 0.327610 & Akaike info criterion & 0.623711 \\
\hline Sum squared residual & 17.70918 & Schwarz criterion & 0.679496 \\
\hline Log likelihood & -49.39168 & Hannan-Quinn criterion & 0.646351 \\
\hline F-statistic & 90.02490 & Durbin-Watson stat. & 0.100254 \\
\hline Prob(F-statistic) & 0.000000 & \multicolumn{2}{|l}{} \\
\hline
\end{tabular}

The estimation of the equation by direct OLS gives the following equation:

LDGEN= 5.96 +0.98LEXR-1.54 LINT

The slope coefficients of all independent variables are statistically significant at least at $1 \%$ level. It is found that the relationship of DGEN index with exchange rateis positive and with interest rateis negative. The result is implying that in Bangladesh, a one percent increase in exchange rate (depreciation of local currency) contributes 0.98 percent increase in market index and a one percent increase in deposit interest rate contributes $1.54 \%$ decrease in market index respectively. Moreover, $\mathrm{F}=90.02$ and $\mathrm{P}=0.000$ imply that the regression model significantly fits the data. Finally, $\mathrm{R}^{2}$ indicates that about 52 percent variation of LDGEN can be explained by total variations in independent variables. But the nonstationarity of variable biased the previous estimation. To confirm the autocorrelation problem we followed Breusch-Godfrey Serial Correlation LM Test and presented in Table-4. The null hypothesis of the LM test is that there is no serial correlation up to lag order $m$, where $m$ is equal to 2 in this case and the Obs*R-squared statistic is the Breusch-Godfrey LM test statistic. The result indicates that we can reject the null hypothesis of no serial auto correlation at $1 \%$ 
significance level. So there exist autocorrelation among the variables and the previously estimated model is a sign of spurious regression.

TABLE 4

BREUSCH-GODFREY SERIAL CORRELATION LM TEST

\begin{tabular}{|c|c|c|c|}
\hline F-statistic & 818.0992 & Prob. F & 0.0000 \\
\hline Obs*R-squared & 152.7799 & Prob. Chi-Square(2) & 0.0000 \\
\hline
\end{tabular}

\subsection{Testing Cointegration}

The next step in our empirical analysis is to test for Cointegration. Since the variables are considered to be $\mathrm{I}(1)$, the Cointegration method is appropriate to estimate the long run relationship between variables. To explore the number of cointegrating vectors, Maximal Eigenvalue and Trace statistics both are used. The results of Trace statistics and Maximum Eigenvalue are shown in Table 5 and Table 6 respectively.

TABLE 5

UNRESTRICTED COINTEGRATION RANK TEST (TRACE)

\begin{tabular}{|c|c|c|c|c|}
\hline \multicolumn{2}{|c|}{ Hypothesized } & \multirow{2}{*}{$\begin{array}{c}\text { Trace } \\
\text { Statistic }\end{array}$} & \multirow{2}{*}{$\begin{array}{c}0.05 \\
\text { Critical Value }\end{array}$} & \multirow[b]{2}{*}{ p-values $* *$} \\
\hline No. of CE(s) & Eigenvalue & & & \\
\hline None * & 0.091837 & 29.99702 & 29.79707 & 0.0474 \\
\hline At most 1 & 0.083960 & 14.29506 & 15.49471 & 0.0752 \\
\hline At most 2 & $4.31 \mathrm{E}-06$ & 0.000702 & 3.841466 & 0.9800 \\
\hline
\end{tabular}

Trace test indicates 1 cointegrating eqn(s) at the 0.05 level

$*$ denotes rejection of the hypothesis at the 0.05 level

**MacKinnon-Haug-Michelis (1999) p-values

TABLE 6

UNRESTRICTED COINTEGRATION RANK TEST (MAXIMUM EIGENVALUE)

\begin{tabular}{|c|c|c|c|c|}
\hline \multicolumn{2}{|c|}{ Hypothesized } & \multirow{2}{*}{$\begin{array}{c}\text { Max-Eigen } \\
\text { Statistic }\end{array}$} & \multirow{2}{*}{\begin{tabular}{|c|}
0.05 \\
Critical Value
\end{tabular}} & \multirow[b]{2}{*}{ p-values $* *$} \\
\hline No. of CE(s) & Eigenvalue & & & \\
\hline None & 0.0 & 15.70197 & 21.13162 & 0.2427 \\
\hline At most $1 *$ & 0.083960 & 14.29435 & 14.26460 & 0.0495 \\
\hline At most 2 & $4.31 \mathrm{E}-06$ & 0.000702 & 3.841466 & 0.9800 \\
\hline
\end{tabular}

Max-eigenvalue test indicates 1 cointegrating eqn(s) at the 0.05 level **MacKinnon-Haug-Michelis (1999) p-values 
The Trace statistic and Maximal Eigen statistic both identified one cointegrating vector. After normalization the cointegrating vector on LDGEN index, normalized cointegrating coefficients were estimated as reported in Table 7.

TABLE 7 NORMALIZED COINTEGRATING COEFFICIENTS

\begin{tabular}{|l|c|c|}
\hline \multicolumn{1}{|c|}{ LDGEN } & LEXR & LINT \\
\hline \multicolumn{1}{|c|}{1.000000} & -1.039236 & 1.707796 \\
\hline Std. Error & 0.44198 & 0.45579 \\
\hline t-value & -2.35132 & 3.74689 \\
\hline P- value & $0.06545^{*}$ & $0.01333^{* *}$ \\
\hline
\end{tabular}

Note:** and * indicate statistically significant at the $5 \%$ and $10 \%$ level, respectively.

The above signs of coefficients are reversed because of the normalization process. The estimation of the equation by Cointegration gives the following one: LDGEN = 1.04 LEXR-1.71 LINT

This clearly shows that in the long run exchange rate has a positive impact on market index. On the other hand, in the long run interest rate has a negative impact on market index. The relationship between market index and all others independent variables are found statistically significant. The result is implying that in Bangladesh in the long run, a one percent increase in exchange rate and in interest rate contributes $1.04 \%$ increase and $1.71 \%$ decrease in market index respectively.

\subsection{Vector Error Correction Model}

In order to find the short run relationships among the variables, vector error correction mechanism has been applied. The results of VECM were shown in Table 8 . 
TABLE 8

ERROR CORRECTION MODEL

\begin{tabular}{|c|c|c|c|}
\hline \multicolumn{4}{|c|}{$\begin{array}{c}\text { Vector Error Correction Estimates } \\
\text { Sample (adjusted): 1997M03 2010M12 } \\
\text { Included observations: } 166 \text { after adjustments }\end{array}$} \\
\hline $\begin{array}{c}\text { Error } \\
\text { Correction: }\end{array}$ & $\Delta$ LDGEN & $\Delta$ LEXR & $\Delta$ LINT \\
\hline $\mathrm{ECM}_{\mathrm{t}-1}$ & $\begin{array}{c}-0.078220 \\
{[-3.48499]^{*}}\end{array}$ & $\begin{array}{c}0.003301 \\
{[1.65317]}\end{array}$ & $\begin{array}{r}0.003749 \\
{[0.64653]}\end{array}$ \\
\hline$\Delta$ LDGEN(-1) & $\begin{array}{c}0.268377 \\
{[3.56887]^{*}} \\
\end{array}$ & $\begin{array}{r}0.000680 \\
{[0.10157]} \\
\end{array}$ & $\begin{array}{c}0.005107 \\
{[0.26285]}\end{array}$ \\
\hline$\Delta \operatorname{LEXR}(-1)$ & $\begin{array}{c}-0.162688 \\
{[-0.18391]}\end{array}$ & $\begin{array}{c}-0.050871 \\
{[-0.64638]}\end{array}$ & $\begin{array}{c}0.091801 \\
{[0.40166]}\end{array}$ \\
\hline$\Delta$ LINT(-1) & $\begin{array}{c}0.817025 \\
{[2.92134] *}\end{array}$ & $\begin{array}{c}-0.032714 \\
{[-1.17976]}\end{array}$ & $\begin{array}{r}0.180975 \\
{[2.24737]}\end{array}$ \\
\hline $\mathrm{C}$ & $\begin{array}{c}0.010906 \\
{[1.35616]}\end{array}$ & $\begin{array}{c}0.003231 \\
{[4.51554]^{* *}}\end{array}$ & $\begin{array}{l}-0.003093 \\
{[-1.48876]}\end{array}$ \\
\hline $\begin{array}{l}\text { R-squared } \\
\text { Adj. R-squared } \\
\text { Sum sq. resids } \\
\text { S.E. equation } \\
\text { F-statistic }\end{array}$ & $\begin{array}{l}0.133518 \\
0.111990 \\
1.490415 \\
0.096215 \\
6.202189\end{array}$ & $\begin{array}{l}\text { Log likelihood } \\
\text { Akaike AIC } \\
\text { Schwarz SC } \\
\text { Mean dependent } \\
\text { S.D. dependent }\end{array}$ & $\begin{array}{c}155.6296 \\
-1.814815 \\
-1.721080 \\
0.010527 \\
0.102101\end{array}$ \\
\hline
\end{tabular}

Notes: i) Figures in parenthesis represent the t-statistics

ii) $* *$ and $*$ indicate statistically significant at the $5 \%$ and $10 \%$ level, respectively.

The above Table shows the speed of adjustment of coefficients. The estimated error correction coefficient indicates that about 7.8 percent deviation of the DGEN index from its long run equilibrium level is corrected each period in 
the short run, while the gaps in the exchange rate and interest rate close by about 0.33 percent and 0.37 percent respectively.

\subsection{Variance Decompositions}

To examine further the short- run dynamic properties of market index, we employ the forecast error variance decomposition. Variance decomposition indicates the amount of information each variable contributes to the other variables in a vector auto regression (VAR) models. The results are presented in Table 9.

TABLE 9

THE RESULTS OF VARIANCE DECOMPOSITIONS

\begin{tabular}{|ccccc|}
\hline Period & S.E. & LDGEN & LEXR & LINT \\
$\mathbf{1}$ & 0.096215 & 100.0000 & 0.000000 & 0.000000 \\
$\mathbf{2}$ & 0.147952 & 98.85411 & 0.006992 & 1.138900 \\
$\mathbf{3}$ & 0.183623 & 98.32287 & 0.004635 & 1.672499 \\
$\mathbf{4}$ & 0.209001 & 98.33471 & 0.005346 & 1.659945 \\
$\mathbf{5}$ & 0.227687 & 98.53018 & 0.010871 & 1.458953 \\
$\mathbf{6}$ & 0.241930 & 98.68133 & 0.021610 & 1.297062 \\
$\mathbf{7}$ & 0.253166 & 98.66460 & 0.037674 & 1.297724 \\
$\mathbf{8}$ & 0.262339 & 98.41574 & 0.059004 & 1.525257 \\
$\mathbf{9}$ & 0.270094 & 97.90461 & 0.085381 & 2.010013 \\
$\mathbf{1 0}$ & 0.276880 & 97.12263 & 0.116442 & 2.760929 \\
$\mathbf{1 1}$ & 0.283018 & 96.07609 & 0.151703 & 3.772210 \\
$\mathbf{1 2}$ & 0.288735 & 94.78191 & 0.190591 & 5.027502 \\
\hline
\end{tabular}

The results of Table 9 show that the dynamic contrast in market index explains $100 \%$ of the components of variation in the first period when the shock by a standard deviation of one in the variable itself, and in the second period it goes to $98.85 \%$ of the error prediction of the variability. During the second period $0.007 \%$ and $1.14 \%$ variation in market index is due to variation in exchange rate and interest rate respectively. The increase in the proportion attributable to variation in exchange rate and interest rate continue to fluctuate with a tendency to increase that up to about $0.19 \%$ and $5.03 \%$ respectively in the period of the twelfth. It is observed that both in the long run and short run interest rate is ranked first in terms of impact on the change of market index. 


\subsection{Impulse Response Function}

Figure 2 shows impulse responses. It shows the impact of a one standard deviation generalized innovation in the exchange rate and interest rate on the market index of Bangladesh. From the figures, we can see that the results are in line with the variance decomposition. Exchange rate has a positive shock where interest rate has a negative shock on the market index.

\section{FIGURE 2: Impulse Response Function}

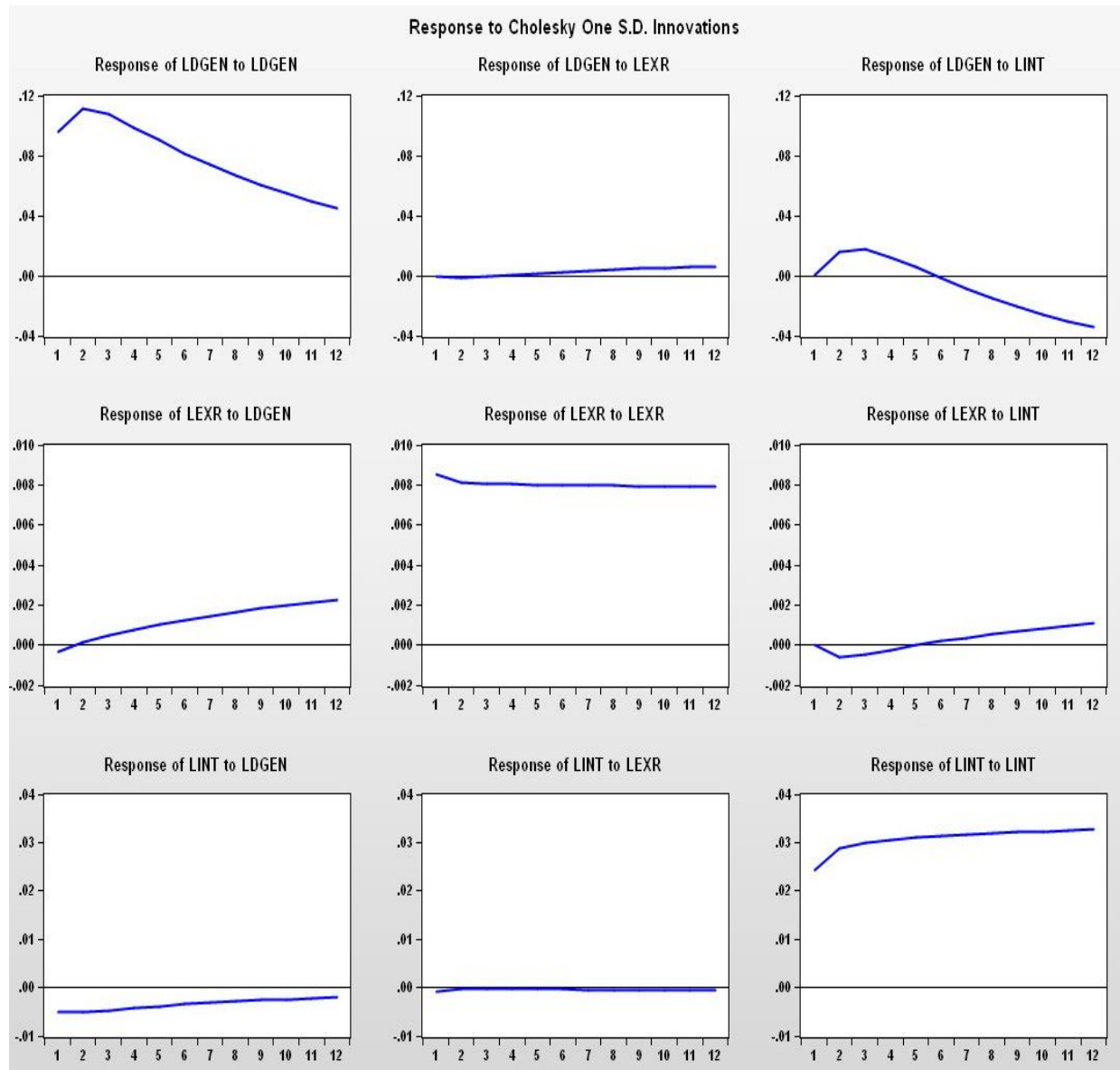




\subsection{Granger Causality Test}

Our final step of analysis is to test for causality between market index and it's determinants in the long run. We carry out Granger causality tests pairwise on series LDGEN, LEXR and LINT with lag length 12.

TABLE 10

GRANGER CAUSALITY TEST

\begin{tabular}{|c|c|c|c|}
\hline Null Hypothesis & $\begin{array}{c}\text { F- } \\
\text { Statistic }\end{array}$ & P-Value & $\begin{array}{c}\text { Granger } \\
\text { Causality }\end{array}$ \\
\hline LEXR does not Granger Cause LDGEN & 0.45549 & 0.9368 & No \\
\hline LDGEN does not Granger Cause LEXR & 2.32531 & $0.0099^{* * *}$ & Yes \\
\hline & & & \\
\hline LINT does not Granger Cause LDGEN & 2.05385 & $0.0243^{* *}$ & Yes \\
\hline LDGEN does not Granger Cause LINT & 0.65909 & 0.7876 & No \\
\hline
\end{tabular}

Notes: i) No. of Obs. $=156$

ii) $* * *$ and $* *$ indicate statistically significant at the $1 \%$ and $5 \%$ level, respectively.

Granger-causality results suggest that the null hypotheses that LDGEN does not Granger cause LEXR is rejected at $1 \%$ significant level and LINTdoes not Granger cause LDGENis rejected at 5\% significant level which means there is a uni-directional causality running from market index to exchange rate and from interest rate to market index.

\section{CONCLUSIONS}

This study attempts to investigate the relationship of stock prices with exchange rate and interest rate in Bangladesh for the period of 1997 to 2010 using different econometric frameworks. The results of unit root test show that all the data series of the variables are non stationary at level and integrated of order one. Our Johansen procedure of Cointegration test suggests at least one cointegrating relationship among the variables. The results of the analysis reveal that in the long runexchange ratehas a positive and interest rate has a negative impact on stock prices where the coefficients of all the explanatory variables are found statistically significant. The estimated error correction coefficient indicates 
that about 7.8 percent deviation of the DGEN index from its long run equilibrium level is corrected each period in the short run. Evidence from Granger causality analysis suggests that there exists a unidirectional causality from market index to exchange rate and from interest rate to market index.

\section{REFERENCES}

Abdalla, I. S. A. and Murinde, V. 1997. Exchange Rate and Stock Price Interactions in Emerging Financial Markets: Evidence on India, Korea, Pakistan and the Philippines, Applied Financial Economics, 7: 25-35.

Aggarwal, R. 1981. Exchange Rates and Stock Prices: A Study of the US Capital Markets under Floating Rates, Akron Business and Economic Review, 12: 7-12.

Ahmad, M.I.; Rehman, R.U., and Raoof, A. 2010. Do Interest Rate, Exchange Rate Effect Stock Returns? A Pakistani Perspective, International Research Journal of Finance and Economics, 50.

Alam, M. M. and Uddin, M. G. S. 2009. Relationship between Interest Rate and Stock Price: Empirical Evidence from Developed and Developing Countries, InternationalJournal for Business and Management, 4 (3): 43-51.

Banerjee, P.K. and Adhikary, B.K. 2009. Dynamic Effects of Changes in Interest Rates and Exchange Rates on the Stock Market Return in Bangladesh, Ritsumeikan Journal of Asia Pacific Studies, 25.

Engle, R. and Granger, C. 1987. Co-integration and Error-correction: Representation, Estimation and Testing, Econometrica, 55: 251-276.

Fama, E. F. and Schwert, G. W. 1977. Asset Returns and Inflation, Journal of Financial Economics, 5: 115-46.

Hasan, A. and Tarij, J. M. 2009. An Empirical Investigation of the Causal Relationship among Monetary Variables and Equity Market Returns, The Lahore Journal of Economics, 14 (1): 115-137.

Hashimoto, Y. and Ito,T. 2004. High-Frequency Contagion between the Exchange Rates and Stock Prices, NBER Working Paper No. 10448, Cambridge.

Imam, M.O. and Amin, A.S.M.M. 2004. Volatility in the Stock Return: Evidence from Dhaka Stock Exchange, Journal of the Institute of Bankers Bangladesh, 51 (1): 01-08.

Islam, M. A. 2003. Exchange Rate Policy of Bangladesh: Not Floating Does Not Mean Sinking. Center of Policy Dialogue (CPD) Occasional Paper series, 2003:20, January 2003.

Johansen, S. 1979. Statistical Analysis of Co Integration Vectors, Journal of Economic Dynamics and Control, June/Sepembert, 231-254. 
Jorion, P. 1990. The Exchange Rates Exposure of US. Multinationals, Journal of Business, 63: 331-345.

Joseph, N. A. and Vezos, P. 2006. The Sensitivity of US Bank's Stock Returns to Interest Rate and Exchange Rate Changes, Managerial Finance, 32(2): 182-199.

Khalid, A.M. and Kawai, M. 2003. Was Financial Market Contagion the source of Economic Crisis in Asia?: Evidence using a Multivariate VAR Model, Journal of Asian Economics, 14: 131-156.

Kumar, M. 2008. A Bivariate Linear and Nonlinear Causality between Stock Prices and Exchange Rates, Economics Bulletin, 29(4).

Leon, N.K. 2008. The Effects of Interest Rates Volatility on Stock Returns and Volatility: Evidence from Korea, Euro Journal of Finance and Economics, 14.

Mishkin, F. 1977. What Depressed the Consumer? The Household Balance Sheet and the 1973-1975 Recession, Brookings Papers on Economic Activity, 1: 123-164.

Modigliani, F. 1971. Monetary Policy and Consumption: Linkages via Interest Rate and Wealth Effects in the FMP Model, Consumer Spending and Monetary Policy: the Linkages, Federal Reserve Bank of Boston Conference Series, 1971: 5, June1971.

Muhammad, N. and Rasheed, A. 2002. Stock Prices and Exchange Rates: Are They Related? Evidence from South Asian Countries, The Pakistan Development Review, 41(4):535-550.

Mukherjee, T. K. and Naka, A. 1995, Dynamic Relations between Macroeconomic Variables and the Japanese Stock Market: An Application of Vector Error Correction Model, The Journal of Financial Research, XVIII (2):223-237.

Rahman, M. L. and Uddin, J. 2009. Dynamic Relationship between Stock Prices and Exchange Rates: Evidence from Three South Asian Countries, International Business Research, 2 (2).

Thomas R. L. 1997: Modern Econometrics: an Introduction, pp 461, United Kingdom: Longman Group. 
APPENDIX-1

TABLE: SUMMARY STATISTICS OF THE STUDY VARIABLES

\begin{tabular}{|l|c|c|c|}
\hline & DGEN index & Exchange rate & Interest Rate \\
\hline Mean & 1755.393 & 59.54945 & 8.232625 \\
\hline Median & 1132.855 & 58.82500 & 8.410000 \\
\hline Maximum & 8602.440 & 71.55000 & 10.57000 \\
\hline Minimum & 480.5500 & 42.45000 & 5.220000 \\
\hline Std. Dev. & 1627.130 & 8.722648 & 1.085244 \\
\hline Skewness & 2.182974 & -0.326405 & -0.775196 \\
\hline Kurtosis & 7.874388 & 1.790321 & 3.926330 \\
\hline & & & \\
\hline Jarque-Bera & 299.7481 & 13.22639 & 22.83263 \\
\hline Probability & 0.000000 & 0.001343 & 0.000011 \\
\hline & & & \\
\hline Observations & 168 & 168 & 168 \\
\hline
\end{tabular}

